\title{
Sunlight may increase the FDG uptake value in primary tumors of patients with non-small cell lung cancer
}

\author{
HASAN MUTLU ${ }^{1}$, ABDULLAH BÜYÜKÇELIK $^{2}$, ESER KAYA $^{3}$, MUSTAFA KIBAR $^{4}$, \\ ERTUĞRUL SEYREK ${ }^{5}$, SINAN YAVUZ ${ }^{2}$ and ZÜLEYHA ÇALIKUŞU ${ }^{5}$
}

\author{
${ }^{1}$ Department of Medical Oncology, Acibadem Kayseri Hospital, Kayseri 38000; ${ }^{2}$ Department of Internal Medicine, \\ Acibadem University School of Medicine, Istanbul; ${ }^{3}$ Department of Nuclear Medicine, Acibadem Kayseri Hospital, \\ Kayseri 38000; ${ }^{4}$ Department of Nuclear Medicine and ${ }^{5}$ Department of Medical Oncology, \\ Acibadem Adana Hospital, Adana, Turkey
}

Received August 26, 2012; Accepted November 29, 2012

DOI: $10.3892 / \mathrm{ol} .2013 .1112$

\begin{abstract}
Currently, positron emission tomography with computerized tomography (PET-CT) is the most sensitive technique for detecting extracranial metastases in non-small cell lung cancer (NSCLC). It has been reported that there is a correlation between the maximal standardized uptake value $\left(\mathrm{SUV}_{\max }\right)$ of primary tumors and prognosis in patients with NSCLC. The effect of sunlight exposure on PET-CT SUV $\mathrm{V}_{\max }$ value is not known. Therefore, we aimed to evaluate the effect of sunlight exposure on PET-CT $\mathrm{SUV}_{\max }$ value in patients with NSCLC. A total of 290 patients with NSCLC from two different regions of Turkey (Kayseri, $\mathrm{n}=168$ and Adana, $\mathrm{n}=122$ ) that have different climate and sunlight exposure intensity, were included in the study. Age, gender, histology of cancer, cancer stage, smoking status, comorbidity and $\mathrm{SUV}_{\max }$ of the primary tumor area at the time of staging were evaluated as prognostic factors. In the multivariate analysis, we detected that the region was the only independent factor affecting $\mathrm{SUV}_{\max }(\mathrm{P}=0.019)$. We identified that warmer climate and more sunlight exposure significantly increases the $\mathrm{SUV}_{\text {max }}$ value of the primary tumor area in patients with NSCLC. Further studies are warranted to clarify the issue.
\end{abstract}

\section{Introduction}

Lung cancer is one of most common types of cancer worldwide and it is the leading cause of cancer-related mortality in both males and females (1). Approximately $85 \%$ of lung cancers are non-small cell lung cancer (NSCLC). Squamous cell carcinoma, adenocarcinoma and large cell carcinoma are

Correspondence to: Dr Hasan Mutlu, Department of Medical Oncology, Acibadem Kayseri Hospital, Seyitgazi Mah, MKP Bulvari, No. 1/1-A Melikgazi, Kayseri 38000, Turkey

E-mail: doktorhasanmutlu@gmail.com

Key words: lung cancer, maximal standardized uptake value, season, positron emission tomography common histologies of NSCLC. The 5-year survival rates in patients with NSCLC vary with the stage of NSCLC. In tumor node metastasis (TNM) stage I, the 5-year survival rate is $73 \%$ (2), while in stage IV it is $13 \%$ (3). The 5 -year survival rate of all patients with NSCLC is $15.7 \%$. Cancer stage (4), performance status (5), ethnicity (6), histopathology (histological subtype, grade, lymphovascular invasion) (7-13), age $(14,15)$, gender $(16)$, carcinoembryonic antigen (CEA) and visceral pleural invasion (17) are prognostic factors in NSCLC. Currently, biomarkers such as p53 (18), K-ras (19), B cell lymphoma-2 (Bcl-2) (20), thyroid transcription factor 1 (TTF-1) (21), epidermal growth factor receptor (EGFR) (22), human epidermal growth factor receptor (HER-2 receptor) (23) and vascular endothelial growth factor (VEGF) (24) have been evaluated as new prognostic factors. Positron emission tomography (PET) with the glucose analogue, $2-\left[{ }^{18} \mathrm{~F}\right]-$ fluoro2-deoxy-d-glucose (FDG) has been successfully used in various stages of care for patients with NSCLC, including staging procedures, radiotherapy planning and evaluation of the response to treatment (25). In addition, PET combined with computerized tomography (PET-CT) is also used for the evaluation of solitary pulmonary nodules (26). While PET-CT has a good negative predictive value in the evaluation of lymph nodes, it has a poor positive predictive value (27). At present, PET-CT is accepted as the most sensitive technique for detecting extracranial metastases from NSCLC $(27,28)$. Since the introduction of PET-CT, a number of studies investigated whether maximal standardized uptake value $\left(\mathrm{SUV}_{\max }\right)$ is a prognostic and/or predictive parameter. Meta-analyses revealed that there is a correlation between $\mathrm{SUV}_{\max }$ and prognosis in patients with NSCLC $(25,29)$. These studies demonstrated that high $\mathrm{SUV}_{\max }$ is associated with poor prognosis. Studies have shown that PET-CT has a predictive value in indicating the effectiveness of various types of chemotherapy $(30,31)$.

Sufficient solar light exposure and vitamin D level may decrease the morbidity and mortality in patients with cancer. There is an inter-regional variability in solar light exposure in Turkey. The Mediterranean region has a warmer climate, whereas internal regions, including inner Anatolia are colder, particularly during winter. Therefore, annual solar light expo- 
sure is more intensive in the Mediterranean region than in internal regions (Table I). The effect of sunlight exposure on PET-CT SUV $V_{\max }$ value is not known. Therefore, in the current study, we aimed to evaluate the effect of sunlight exposure on

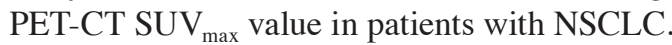

\section{Materials and methods}

Subjects. Patients with NSCLC from two different regions of Turkey (Kayseri and Adana, which have different climate and sunlight exposure intensity) were included in this study. Between 2009 and 2012, a total of 290 consecutive patients with NSCLC from Acibadem Kayseri Hospital and Acibadem Adana Hospital were analyzed retrospectively, using hospital records. All patients had a new diagnosis of NSCLC and PET-CT was used for baseline staging. The patients were divided into two groups, the Kayseri region, with a colder climate $(n=168)$ and the Adana region, with a warmer climate $(n=122)$. Staging was made according to the $7^{\text {th }}$ version of TNM lung cancer staging system. Age, gender, histological subtypes of cancer, cancer stage, smoking status (current or former smoker), comorbidity and $\mathrm{SUV}_{\max }$ of the primary tumor area at the time of staging were recorded. This study was reviewed and approved by Ethics Committee of Erciyes University, Kayseri, Turkey. Written informed patient consent was obtained from all patients.

PET-CT protocol. Patients were intravenously injected with $\sim 10 \mathrm{mCi}(370 \mathrm{MBq})$ FDG. After $1 \mathrm{~h}$ rest in a silent room, the patients were imaged using an integrated PET-CT camera. The PET-CT scan was performed using a Siemens Biograph 6 PET-CT (LSO, 3D). The CT portion of the study was performed without intravenous contrast medium and used for defining anatomical marks and for attenuation correction of the PET reconstruction. The two centers used the same PET-CT protocols and the same PET-CT machine.

Statistical analysis. Descriptive tests, Chi-square tests, independent samples tests and covariate analyses were performed using Statistical Package for the Social Sciences 16.0 (SPSS 16.0, SPSS Inc., Chicago, IL, USA). P<0.05 was considered to indicate a statistically significant difference.

\section{Results}

Annual solar light exposure was more intensive in the Mediterranean region than the internal region. The hours of sunshine per day for the Kayseri and Adana regions are given in Table I.

Patient characteristics are given in Table II. The mean ages of patients from Kayseri and Adana were 62.1 \pm 9.2 and $61.7 \pm 10.5$, respectively $(\mathrm{P}=0.733)$. The male to female ratio was similar in the two groups $(\mathrm{P}=0.457)$. There was no significant difference in the histology of cancer $(\mathrm{P}=0.117)$, cancer stage $(\mathrm{P}=0.188)$, smoking status $(\mathrm{P}=0.334)$ and diabetes mellitus between the two groups $(\mathrm{P}=0.699)$. The mean $\mathrm{SUV}_{\max }$ of patients from the Kayseri region was $13.1 \pm 6.4$ and $14.6 \pm 5.8$ for the Adana region $(\mathrm{P}=0.038)$. In order to identify which factors effect $\mathrm{SUV}_{\max }$, we performed univariate analysis. The results of univariate analysis are presented in Table III. This
Table I. Hours of sunshine per day in the Kayseri and Adana regions of Turkey.

\begin{tabular}{lcc}
\hline & \multicolumn{2}{c}{ Average hours of sunshine per day } \\
\cline { 2 - 3 } Months & Kayseri region & Adana region \\
\hline January & 3 & 5 \\
February & 4 & 5 \\
March & 5 & 6 \\
April & 6 & 7 \\
May & 8 & 10 \\
June & 10 & 11 \\
July & 12 & 11 \\
August & 11 & 11 \\
September & 9 & 9 \\
October & 7 & 7 \\
November & 5 & 6 \\
December & 3 & 5 \\
Average (month) & 210.9 & 237.9 \\
Average (year) & 2531 & 2855 \\
\hline
\end{tabular}

$\mathrm{P}=0.475$ between the two groups.

Table II. Patient's baseline characteristics.

\begin{tabular}{|c|c|c|c|}
\hline Parameters & Kayseri region & Adana region & P-value \\
\hline Age (years) & $62.1 \pm 9.2$ & $61.7 \pm 10.5$ & 0.733 \\
\hline Gender (n) & & & 0.457 \\
\hline Male & 158 & 112 & \\
\hline Female & 10 & 10 & \\
\hline Histology & & & 0.117 \\
\hline $\begin{array}{l}\text { Squamous cell } \\
\text { carcinoma }\end{array}$ & 63 & 42 & \\
\hline Adenocarcinoma & 49 & 33 & \\
\hline Others & 1 & 6 & \\
\hline $\begin{array}{l}\text { Not otherwise } \\
\text { specified }\end{array}$ & 55 & 41 & \\
\hline TNM stage & & & 0.188 \\
\hline Stage 1 & 4 & 3 & \\
\hline Stage 2 & 17 & 23 & \\
\hline Stage 3 & 75 & 52 & \\
\hline Stage 4 & 72 & 44 & \\
\hline Smoking & & & 0.334 \\
\hline Yes & 129 & 101 & \\
\hline No & 36 & 21 & \\
\hline Diabetes mellitus & 8 & 7 & 0.699 \\
\hline $\begin{array}{l}\mathrm{SUV}_{\text {max }} \\
(\text { mean } \pm \mathrm{SD})\end{array}$ & $13.1 \pm 6.4$ & $14.6 \pm 5.8$ & 0.038 \\
\hline
\end{tabular}

$\mathrm{SD}$, standard deviation; TNM, tumor node metastasis; $\mathrm{SUV}_{\max }$, maximal standardized uptake value. 
Table III. Results of univariate analysis between $\mathrm{SUV}_{\max }$ and various parameters.

\begin{tabular}{lc}
\hline Parameter & P-value \\
\hline Region & 0.027 \\
Age & 0.103 \\
Gender & 0.168 \\
Histology & 0.906 \\
Stage & 0.901 \\
Smoking status & 0.668 \\
Diabetes mellitus & 0.142 \\
\hline
\end{tabular}

analysis revealed that the region was the only independent factor affecting $\mathrm{SUV}_{\max }(\mathrm{P}=0.027)$.

\section{Discussion}

In the present study, we investigated whether $\mathrm{SUV}_{\max }$ is affected by sunlight exposure. We identified that $\mathrm{SUV}_{\max }$ is significantly different in two different climates in Turkey. The subjects in the Adana region, which has a warmer climate and a greater annual average sunlight exposure, had a higher $\mathrm{SUV}_{\max }$ compared with that in the subjects in the Kayseri region. The evaluated factors such as age, gender, histology, cancer stage, smoking and diabetes mellitus had no effect on $\mathrm{SUV}_{\max }$. We identified that sunlight exposure was the only factor that significantly affected the $\mathrm{SUV}_{\max }$ of the tumor area in patients with NSCLC. We suggest that higher $\mathrm{SUV}_{\max }$ may be a prognostic factor for poor survival in lung cancer; however, our results oppose previous studies. In previous studies, patients who had more sunlight exposure or lived in a warmer climate had a better prognosis regarding survival. It was thought that this survival advantage may depend on vitamin D3 $\left(1,25(\mathrm{OH})_{2} \mathrm{D} 3\right)$ that is produced by ultraviolet $\mathrm{B}$ light isomerization of 7-dehydrocholestrol in the epidermis $(32,33)$. Vitamin D3 exerts antiproliferative effects and inhibits growth and metastasis of lung cancer cells (34-40). A prospective study analyzed serum vitamin D levels in 6,937 patients with lung cancer (41). The association between the serum level of vitamin D3 and lung cancer risk was observed as the highest vs. lowest tertile with an odds ratio of 0.72 . It has been demonstrated that improved survival in early stage lung cancer is associated with higher circulating levels of vitamin D3 $(42,43)$. Patients diagnosed in summer and autumn are associated with improved survival compared to those diagnosed in winter. Cumulative sunlight exposure in the months preceding diagnosis is also a predictor of subsequent survival, although the season of diagnosis is a stronger predictor than cumulative sunlight exposure (44).

We identified that warmer climate and greater sunlight exposure significantly increases the $\mathrm{SUV}_{\max }$ value in the primary tumor area in patients with NSCLC. Further studies are warranted to clarify the correlation between high $\mathrm{SUV}_{\max }$, greater sunlight exposure, vitamin D3 and survival in patients with NSCLC.

\section{Acknowledgements}

The authors would like to thank Isa Dogan.

\section{References}

1. Jemal A, Bray F, Center MM, Ferlay J, Ward E and Forman D: Global cancer statistics. CA Cancer J Clin 61: 69-90, 2011.

2. Ries LAG, Eisner MP, Kosary CL, et al (eds): SEER Cancer Statistics Review, 1975-2002. National Cancer Institute, Bethesda, MD, 2005.

3. Goldstraw P, Crowley J, Chansky K, et al: The IASLC Lung Cancer Staging Project: proposals for the revision of the TNM stage groupings in the forthcoming (seventh) edition of the TNM Classification of malignant tumours. J Thorac Oncol 2: 706-714, 2007.

4. Caglar HB, Baldini EH, Othus M, et al: Outcomes of patients with stage III nonsmall cell lung cancer treated with chemotherapy and radiation with and without surgery. Cancer 115: 4156-4166, 2009.

5. Hoang T, Xu R, Schiller JH, Bonomi P and Johnson DH: Clinical model to predict survival in chemonaive patients with advanced non-small-cell lung cancer treated with third-generation chemotherapy regimens based on eastern cooperative oncology group data. J Clin Oncol 23: 175-183, 2005.

6. Blackstock AW, Herndon JE II, Paskett ED, Perry MC, et al: Outcomes among African-American/non-African-American patients with advanced non-small-cell lung carcinoma: report from the Cancer and Leukemia Group B. Blackstock J Natl Cancer Inst 94: 284-290, 2002.

7. Vansteenkiste JF, De Leyn PR, Deneffe GJ, et al: Survival and prognostic factors in resected N2 non-small cell lung cancer: a study of 140 cases. Leuven Lung Cancer Group. Ann Thorac Surg 63: 1441-1450, 1997.

8. No authors listed: Postoperative T1 N0 non-small cell lung cancer. Squamous versus nonsquamous recurrences. The Lung Cancer Study Group. J Thorac Cardiovasc Surg 94: 349-354, 1987.

9. Harpole DH Jr, Herndon JE II, Young WG Jr, Wolfe WG and Sabiston DC Jr: Stage I nonsmall cell lung cancer. A multivariate analysis of treatment methods and patterns of recurrence. Cancer 76: 787-796, 1995.

10. Takise A, Kodama T, Shimosato Y, Watanabe S and Suemasu K: Histopathologic prognostic factors in adenocarcinomas of the peripheral lung less than $2 \mathrm{~cm}$ in diameter. Cancer 61: 2083-2088, 1988.

11. Shields TW: Prognostic significance of parenchymal lymphatic vessel and blood vessel invasion in carcinoma of the lung. Surg Gynecol Obstet 157: 185-190, 1983.

12. Berghmans T, Paesmans M and Sculier JP: Prognostic factors in stage III non-small cell lung cancer: a review of conventional, metabolic and new biological variables. Ther Adv Med Oncol 3: 127-138, 2011.

13. Barlési F, Doddoli C, Torre JP, et al: Comparative prognostic features of stage IIIAN2 and IIIB non-small-cell lung cancer patients treated with surgery after induction therapy. Eur J Cardiothorac Surg 28: 629-634, 2005.

14. Riquet M, Bagan P, Le Pimpec Barthes F, et al: Completely resected non-small cell lung cancer: reconsidering prognostic value and significance of N2 metastases. Ann Thorac Surg 84: 1818-1824, 2007.

15. Kameyama K, Huang CL, Liu D, et al: Problems related to TNM staging: patients with stage III non-small cell lung cancer. J Thorac Cardiovasc Surg 124: 503-510, 2002.

16. Albain KS, Swann RS, Rusch VW, et al: Radiotherapy plus chemotherapy with or without surgical resection for stage III non-small-cell lung cancer: a phase III randomised controlled trial. Lancet 374: 379-386, 2009.

17. Niizeki H, Morikawa T, Okushiba S, Kondo S and Katoh H: Survival and prognostic factors in resected cN2-pN0 non-small cell lung cancer. Ann Thorac Cardiovasc Surg 10: 9-13, 2004.

18. Mitsudomi T, Hamajima N, Ogawa $\mathrm{M}$ and Takahashi $\mathrm{T}$ : Prognostic significance of p53 alterations in patients with non-small cell lung cancer: a meta-analysis. Clin Cancer Res 6: 4055-4063, 2000.

19. Mascaux C, Iannino N, Martin B, et al: The role of RAS oncogene in survival of patients with lung cancer: a systematic review of the literature with meta-analysis. Br J Cancer 92: 131-139, 2005. 
20. Martin B, Paesmans M, Berghmans T, et al: Role of Bcl-2 as a prognostic factor for survival in lung cancer: a systematic review of the literature with meta-analysis. Br J Cancer 89: 55-64, 2003.

21. Berghmans T, Paesmans M, Mascaux C, et al: Thyroid transcription factor 1 - a new prognostic factor in lung cancer: a meta-analysis. Ann Oncol 17: 1673-1676, 2006.

22. Nakamura H, Kawasaki N, Taguchi M and Kabasawa K: Survival impact of epidermal growth factor receptor overexpression in patients with non-small cell lung cancer: a meta-analysis. Thorax 61: 140-145, 2006

23. Meert AP, Martin B, Paesmans M, et al: The role of HER-2/neu expression on the survival of patients with lung cancer: a systematic review of the literature. Br J Cancer 89: 959-965, 2003.

24. Zhan P, Wang J, Lv XJ, et al: Prognostic value of vascular endothelial growth factor expression in patients with lung cancer: a systematic review with meta-analysis. J Thorac Oncol 4: 1094-1103, 2009

25. Paesmans M, Berghmans T, Dusart M, et al: Primary tumor standardized uptake value measured on fluorodeoxyglucose positron emission tomography is of prognostic value for survival in non-small cell lung cancer: update of a systematic review and meta-analysis by the European Lung Cancer Working Party for the International Association for the Study of Lung Cancer Staging Project. J Thorac Oncol 5: 612-619, 2010

26. De Wever W, Vankan Y, Stroobants S and Verschakelen J: Detection of extrapulmonary lesions with integrated PET/CT in the staging of lung cancer. Eur Respir J 29: 995-1002, 2007.

27. Antoch G, Stattaus J, Nemat AT, et al: Non-small cell lung cancer: dual-modality PET/CT in preoperative staging. Radiology 229 526-533, 2003

28. Gámez C, Rosell R, Fernández A, et al: PET/CT fusion scan in lung cancer: current recommendations and innovations. J Thorac Oncol 1:74-77, 2006.

29. Nair VS, Krupitskaya Y and Gould MK: Positron emission tomography $18 \mathrm{~F}$-fluorodeoxyglucose uptake and prognosis in patients with surgically treated, stage I non-small cell lung cancer: a systematic review. J Thorac Oncol 4: 1473-1479, 2009.

30. Pöttgen C, Levegrün S, Theegarten D, et al: Value of 18F-fluoro2-deoxy-D-glucose-positron emission tomography/computed tomography in non-small-cell lung cancer for prediction of pathologic response and times to relapse after neoadjuvant chemoradiotherapy. Clin Cancer Res 12: 97-106, 2006.

31. Hoekstra CJ, Stroobants SG, Smit EF, et al: Prognostic relevance of response evaluation using [18F]-2-fluoro-2-deoxy-D-glucose positron emission tomography in patients with locally advanced non-small-cell lung cancer. J Clin Oncol 23: 8362-8370, 2005.

32. Zhu K, Bruce D, Austin N, Devine A, Ebeling PR and Prince RL: Randomized controlled trial of the effects of calcium with or without vitamin D on bone structure and bone-related chemistry in elderly women with vitamin D insufficiency. J Bone Miner Res 23: 1343-1348, 2008.
33. Beer TM and Myrthue A: Calcitriol in cancer treatment: from the lab to the clinic. Mol Cancer Ther 3: 373-381, 2004.

34. Higashimoto Y, Ohata M, Nishio K, et al: 1 alpha, 25-dihydroxy vitamin D3 and all-trans-retinoic acid inhibit the growth of a lung cancer cell line. Anticancer Res 16: 2653-2659, 1996.

35. Wood AW, Chang RL, Huang MT, Uskokovic M and Cooney AH: 1 $\alpha, 25$-dihydroxy vitamin D3 inhibits phorbol ester-dependent chemical carcinogenesis in mouse skin. Biochem Biophys Res Commun 116: 605-611, 1983

36. Ordonez-Moran P, Larriba MJ, Pendas-Franco N, Aguilera O, Gonzalez-Sancho JM and Munoz A: Vitamin D and cancer: an update of in vitro and in vivo data. Front Biosci 10: 2723-2749, 2005.

37. Hansen CM, Binderup L, Hamberg KJ and Carlberg C: Vitamin $\mathrm{D}$ and cancer: effects of $1,25(\mathrm{OH}) 2 \mathrm{D} 3$ and its analogs on growth control and tumorigenesis. Front Biosci 6: 820-848, 2001.

38. Trump DL, Hershberger PA, Bernardi RJ, et al: Anti-tumor activity of calcitriol: pre-clinical and clinical studies. J Steroid Biochem Mol Biol 89-90: 519-526, 2004.

39. Nakagawa K, Sasaki Y, Kato S, Kubodera N and Okano T: 22-Oxa-1a,25- dihydroxyvitamin D3 inhibits metastasis and angiogenesis in lung cancer. Carcinogenesis 26: 1044-1054, 2005.

40. Young MR, Ihm J, Lozano Y, Wright MA and Prechel MM: Treating tumor-bearing mice with vitamin D3 diminishes tumorinduced myelopoiesis and associated immunosuppression, and reduces tumor metastasis and recurrence. Cancer Immunol Immunother 41: 37-45, 1995.

41. Kilkkinen A, Knekt P, Heliövaara M, et al: Vitamin D status and the risk of lung cancer: a cohort study in Finland. Cancer Epidemiol. Biomarkers Prev 17: 3274-3278, 2008.

42. Zhou W, Heist RS, Liu G, et al: Vitamin D is associated with improved survival in early-stage non-small cell lung cancer patients. Cancer Epidemiol Biomarkers Prev 14: 2303-2309, 2005.

43. Zhou W, Heist RS, Liu G, Asomaning K, et al: Circulating 25-hydroxyvitamin D levels predict survival in early-stage nonsmall-cell lung cancer patients. J Clin Oncol 25: 479-485, 2007.

44. Lim HS, Roychoudhuri R, Peto J, Schwartz G, Baade P and Møller H: Cancer survival is dependent on season of diagnosis and sunlight exposure. Int J Cancer 119: 1530-1536, 2006. 